
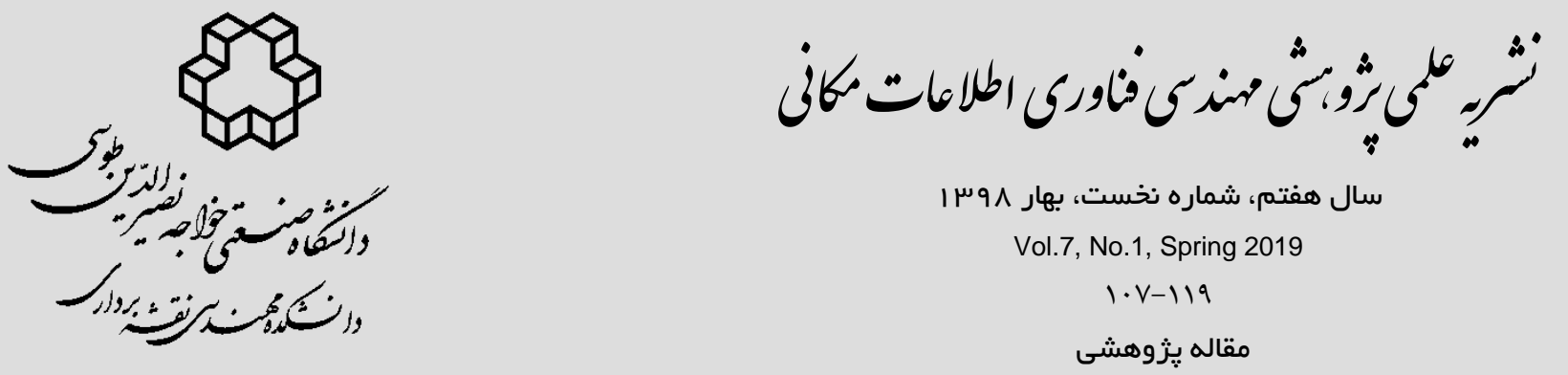

اين مقاله در دومين كنفرانس ملى مهندسى فناورى اطلاعات مكانى بهعنوان مقاله بركزيده انتخاب شده است كه يس از تكميل، داورى مجدد

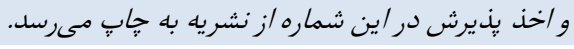

بازيابى فاز تداخلسنجى رادارى به كمك انتقال دادههاى نامنظم به فضاى منظم

\author{
امين توكلى اصطهباناتى "،.مريم دهقانى

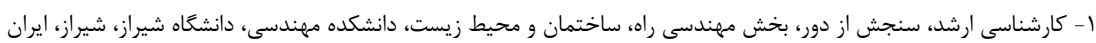

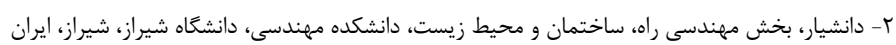

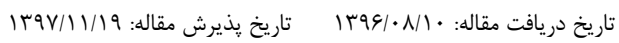

جكيده

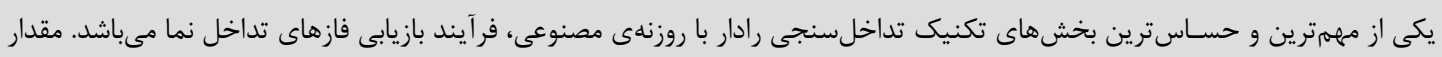

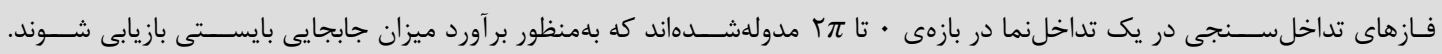

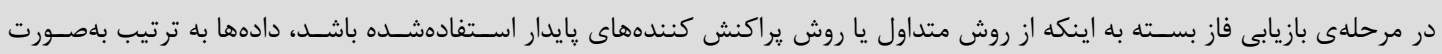

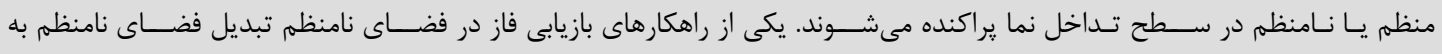

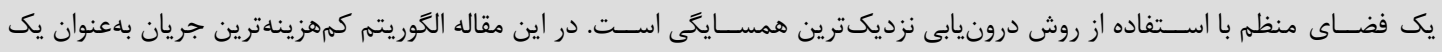

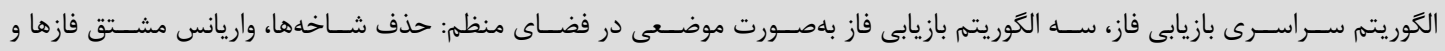

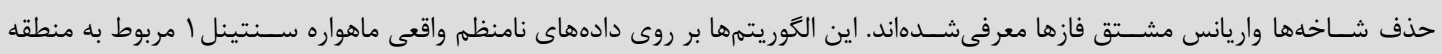
دشت سيرجان اعمال شدهاند و نتايج آنها با يكديكر مقايسه شده است إندان.

كليدوازهها: تداخلسنجى رادارى، بازيابى فاز، سنتينل I. - إ.

"نويسنده مكاتبه كنده: شيراز- ميدان نمازى - دانشكده فنى و مهندسى - - بخش راه ساختمان و محيط زيست 
تداخل نما ها نقاطى وجود دارند كه اختلاففاز آنها

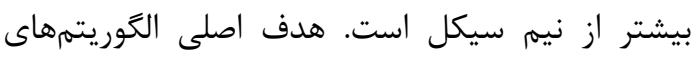
بازيابى فاز شناسايى و تعيين دقيق محل اين نقاط

مجموعهاى از فازهاى بازيابى شده حاوى اطلاعاتى

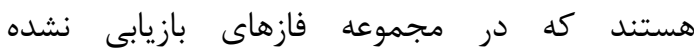

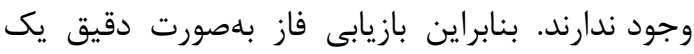

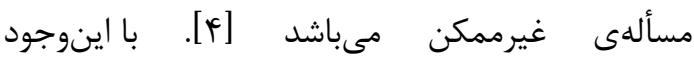
الكوريتمهاى متفاوتى تاكنون ارائهشدهاند كه در ادامه باله به معرفى و ارزيابى برخى از آنها خواهيم يرداخت.

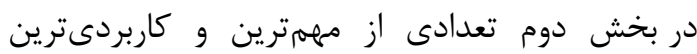

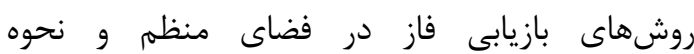
اعمال آنها بر روى فضاى نامنظم بيان خواهد شد. در بخش سوم نتايج اعمال الكوريتمهاى معرفىشده برائ

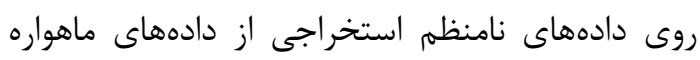

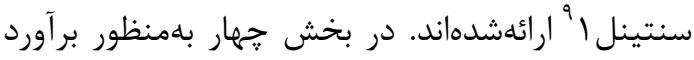

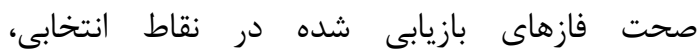

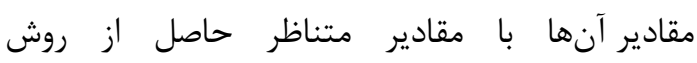
تداخلسنجى متداول مقايسه شده است و در انتهاديا،

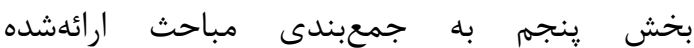
اختصاص دادهده است.

$$
\text { r - بازيابى فاز }
$$

بهطوركلى صرفنظر از نحوهى توزيع نقاط، فازهاى

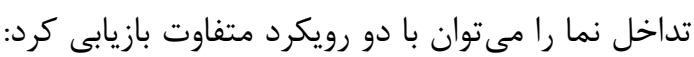

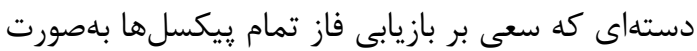

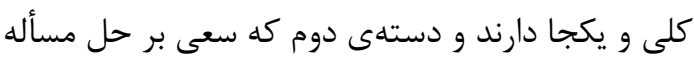

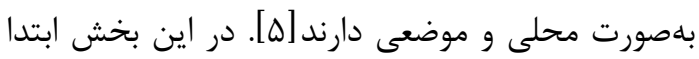

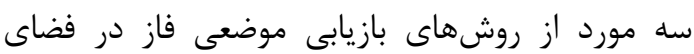

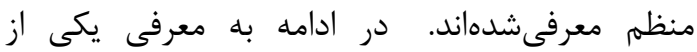
متداولترين روشهاى بازيابى فاز بهصورت كلى و يكجا

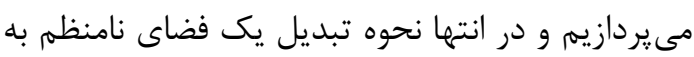
يك فضاى منظم معرفى خواهد شد.
| - 1- (- مقدمه

تداخل سنجى رادارى بر اساس تركيب دو يا جند

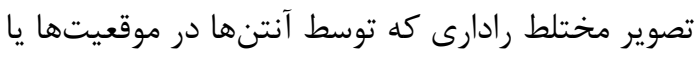

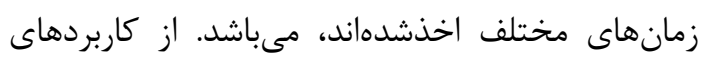
تكنيك تداخلسنجى رادارى مى توان به بهدست آوردن تويوكرافى يا ميزان جابجايى ناشى از فرونشست،

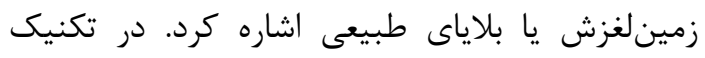
تداخل سنجى تصاوير مختلط رادارى كه شامل دامنه و

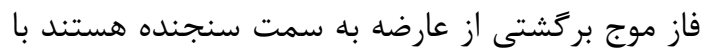

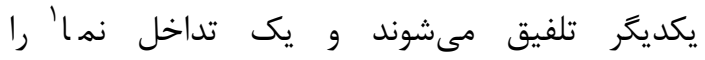
تشكيل مى دهند. مشاهدات تداخل سنجى مجموعهاى از

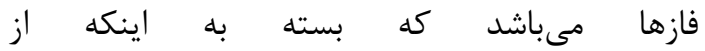

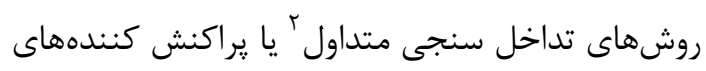

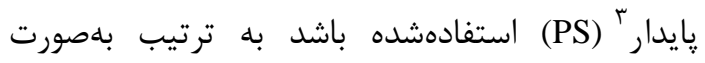

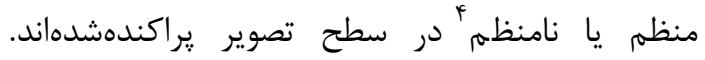
فازهاى يك تداخل نما مقدارى بين صفر و 2 2 دارند كه به اين صورت قابل استفاده نمى باشند [1 [1].

بازيابى فازه كه يكى از مراحل روش تداخل سنجى

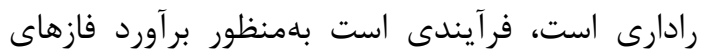

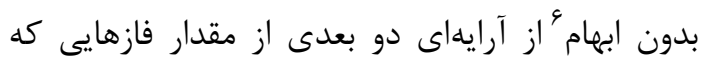

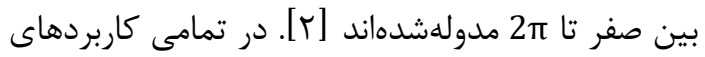

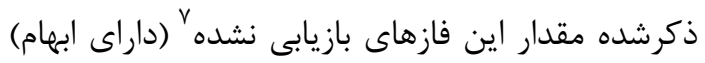

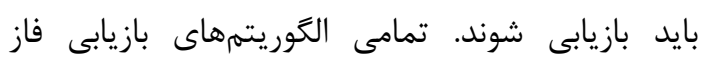

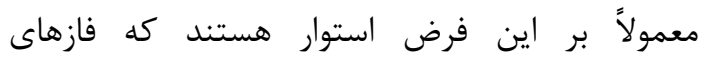

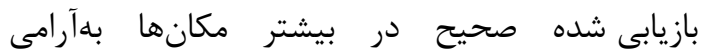
تغيير مىكنند يعنى مقادير ريكسل هاى همسايه بايد

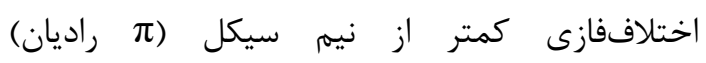
داشته باشند (شرط نايكوئيست) [ب]. ليكن در اكثر آنر

\footnotetext{
${ }^{1}$ Interferogram

${ }^{2}$ Conventional

${ }^{3}$ Persistent Scatterer (PS)

${ }^{4}$ Sparse

${ }^{5}$ Unwrapping

${ }^{6}$ Unwrapped

${ }^{7}$ Wrap

${ }^{8}$ Nyquist Theorem
} 
كه در آن

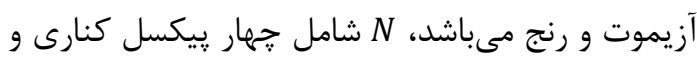

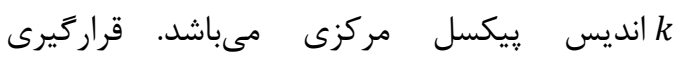

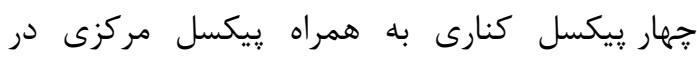
شكل (1) نمايش دادهشده است.

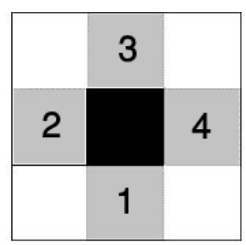

شكل ا: نحوهى قرار تيرى پييكسلها. بيكسل مركزى به به

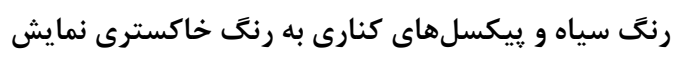
دادهشدهاند.

r-Y-1-r حذف شاخهها (حذف باقىماندهها)

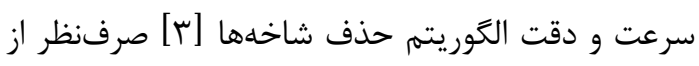
عدم توانايىاش در ارائه يك راهحل كامل، آن دآ را بسيار

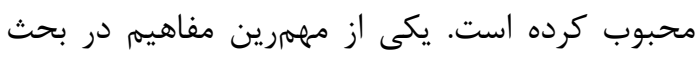

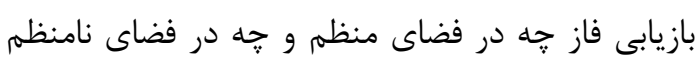

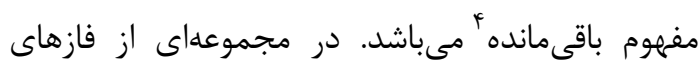

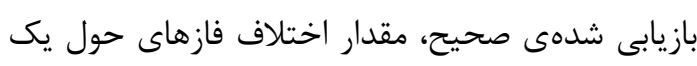

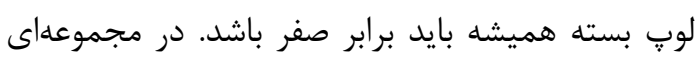

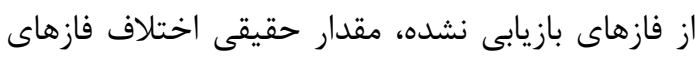

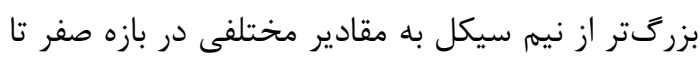

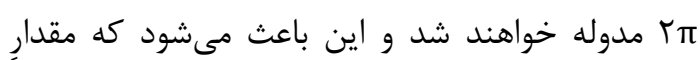

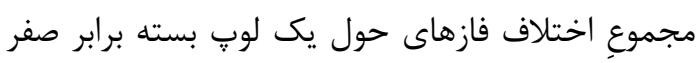

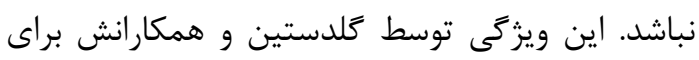

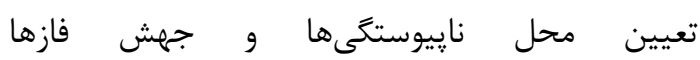

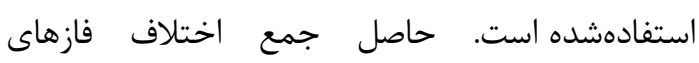

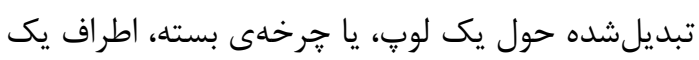

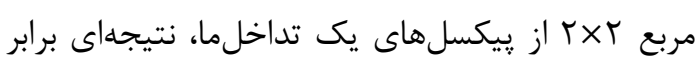

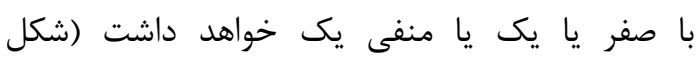
Error! Reference source not found.( $(\zeta)$

\footnotetext{
${ }^{3}$ Branch-cut (residue-cut)

${ }^{4}$ Residue
}

ك-1- بازيابى فاز بازيابى فاز به صورت موضعى در فضاى منظم برخلاف روشهاى مبتنى بر يراكنش كنندههاى يايدار،

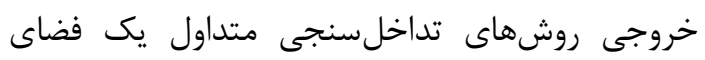

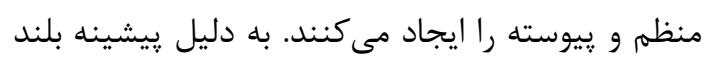

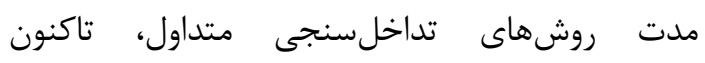
روشهاى متعددى براى بازيابى فاز بر اساس آنهائ آنها

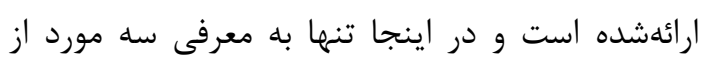

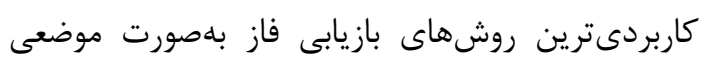

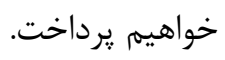
روشهاى بازيابى فاز بلهصورت موضعى از ايدهى دنبال كننده مسير' براى بازيابى فاز استفاده مئى مكند.

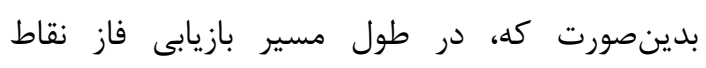

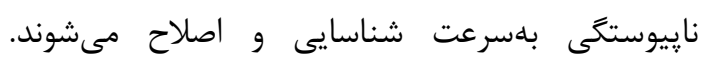

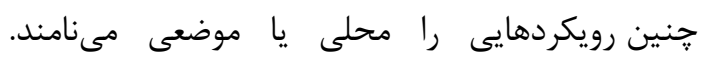

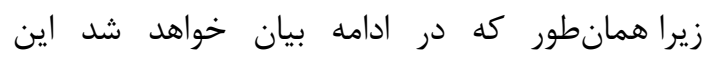

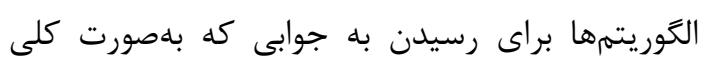

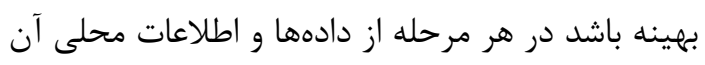
مرحله استفاده مى كنند. r-1-1 - واريانس مشتق فازها؟ همانطور كه بيان شد الكوريتمهاى بازيابى موضعى فاز

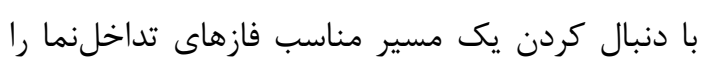

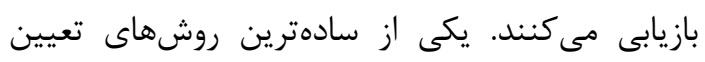

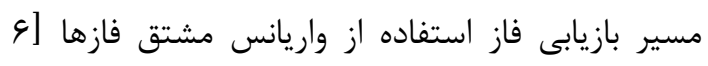
[Vو است. از اين روش براى ساخت يك نقشه كيفيت

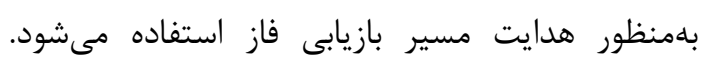

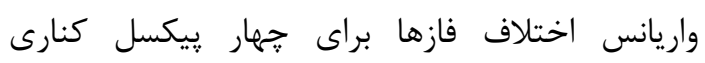

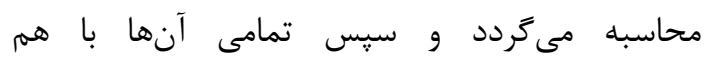

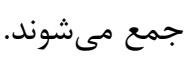
$P D V^{k}=\sum_{n=1}^{N} \sigma_{x}^{2}(n)+\sigma_{y}^{2}(n) \quad$ (1)

${ }^{1}$ Path following

${ }^{2}$ Phase Derivative Variance (PDV) 
كمتر از نيم سيكل است، اين جوابهاى غير صفر نشاندهندهى آشفتگى و كسيختخى بين دادهيا
تعيين باقىمانده در شكل (r) نشان دادهشه است.

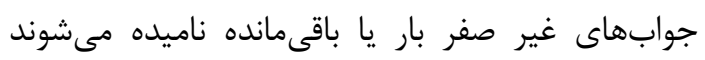
بر اساس اين فرض كه تفاضل فازهاى بازيابى نشده

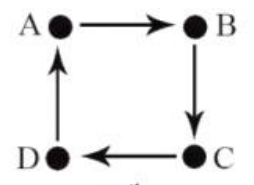

الف)

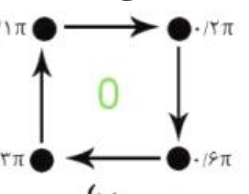

(ب

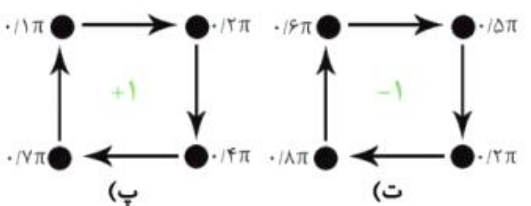

$\left[\frac{\Psi_{B}-\Psi_{A}}{\pi}\right]+\left[\frac{\Psi_{C}-\Psi_{B}}{\pi}\right]+\left[\frac{\Psi_{D}-\Psi_{C}}{\pi}\right]+\left[\frac{\Psi_{A}-\Psi_{D}}{\pi}\right]=$

$0.1+0.4-0.2$

ب) $0.1+0.2+0.3+(0.1-0.7+1)$

ڤ) $0.1+0.2+0.3+(0.1-0.7+1)$

ت) $-0.1-0.3+(0.8-0.2-1)-0.2$

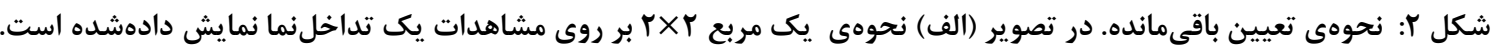

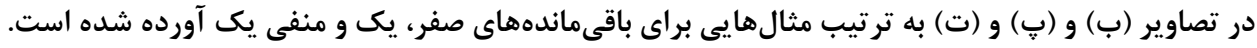

اين الكوريته عموماً در مناطقى از تداخل نما كه

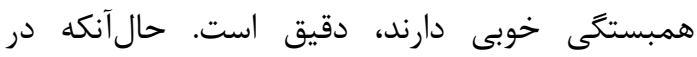

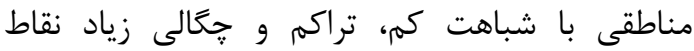

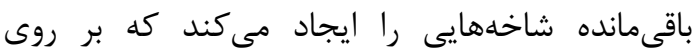

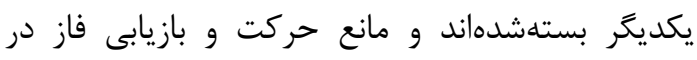
كل مناطق تداخل نما مىشود. نتيجه اين اتفاق

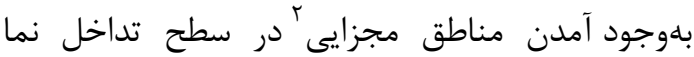
است.

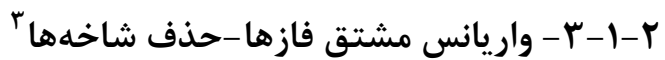
در الكوريتم حذف شاخهها اكر شاخهها بهدرستى

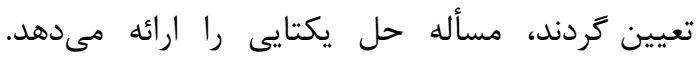

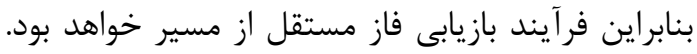
از اين ويزگى براى بهبود كارايى ديكر الكوريتمها

\footnotetext{
${ }^{2}$ Isolated

${ }^{3}$ Phase derivative values - Branch cut
}

در اين الكوريته باقىماندههاى غير صفر، يا بارها،

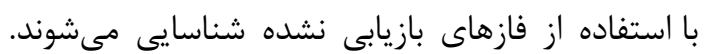
يك شاخه بين اين باقىمانده و نزديكترين باقىمانده بعدى، صرفنظر از علامت آن (مثبت يا منفى بودن)

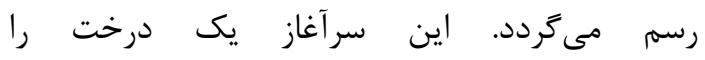

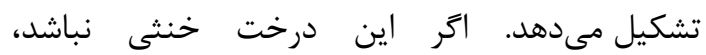

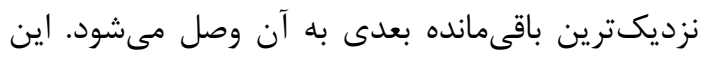

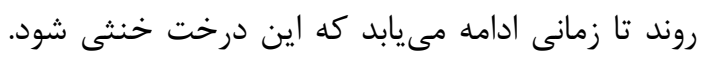
در اين هنگام يك بار، باقىمانده، غير صفر ديكر بلهعنوان ريشهى

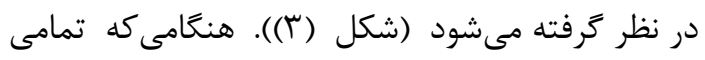

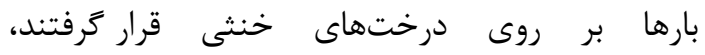

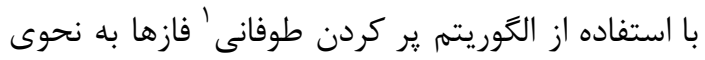

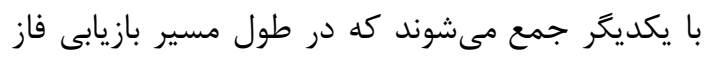

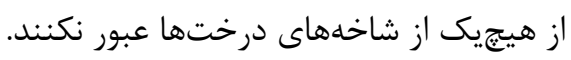

${ }^{1}$ Flood-fill 


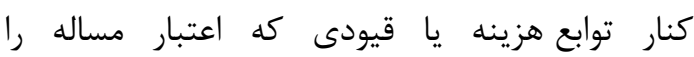

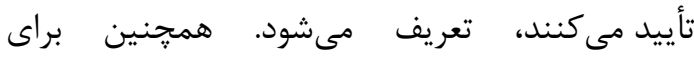

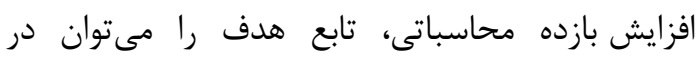

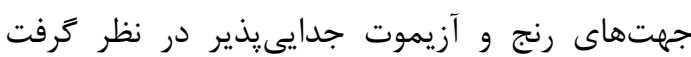

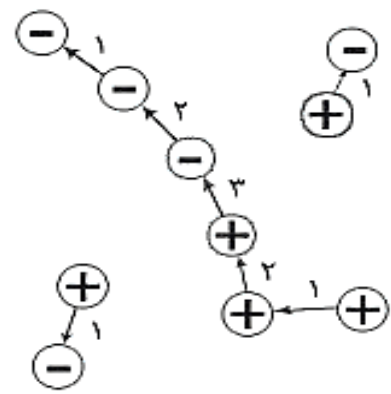

شكل rا: در الكَوريتم حذف شاخهها، احتمال رخ دادن كسيختكى در درختهاى خنثى است، عددها بيانكر اندازهى بار هر شاخه مى خباشند.

استفاده مىشود. الكوريتم ارائهشده در اينجا تركيبى از

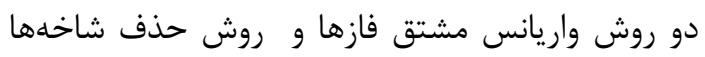

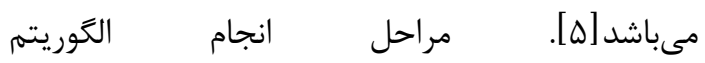

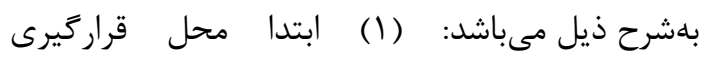

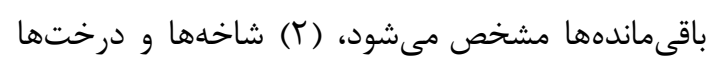

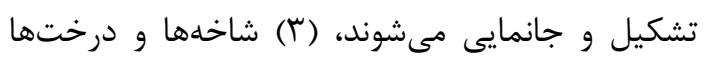

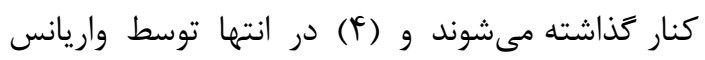

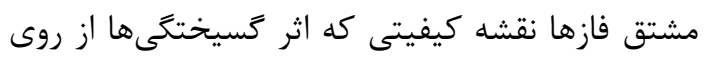
آن برداشتهشده است، تعيين مىشود. r-r- بازيابى فاز بهصورت سراســـى و كلـى در

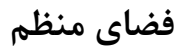
در روشهاى بازيابى فاز بهصورت سراسرى،

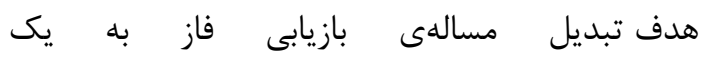

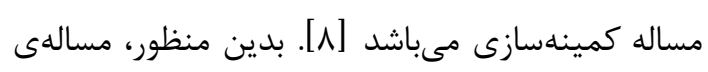

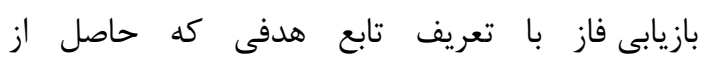

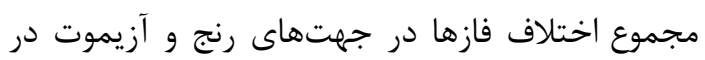
$\operatorname{minimize}\left\{\sum_{i} \sum_{j} h_{i, j}^{r}\left(\Delta \varphi_{i, j}^{r}-\Delta \Psi_{i, j}^{r}\right)+\sum_{i} \sum_{j} h_{i, j}^{a}\left(\Delta \varphi_{i, j}^{a}-\Delta \Psi_{i, j}^{a}\right)\right\}$

1- مقداردهى اوليه شبكه با استفاده از يك جريان

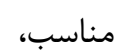
r- استفاده از الكوريتم دايجستر آ جهت يافتن : جرخهاى منفى، r- القا كردن جريان بر روى آنها براى حذف اين خرخههاى منفى،

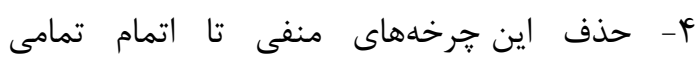

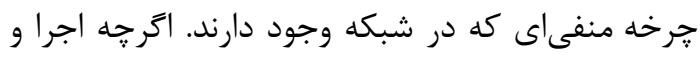

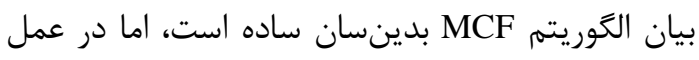

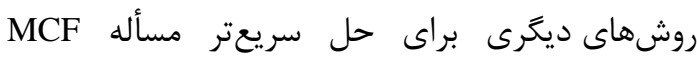

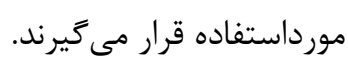

${ }^{2}$ Dijkstra
كه بدون ابهام و اختلاف فازهاى داراى ابهام. a و r بهترتيب

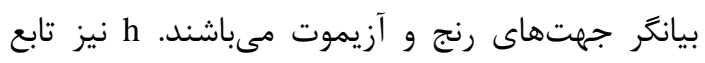

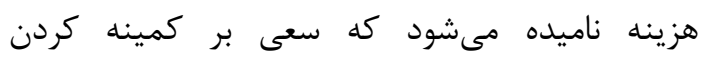
هزينهى كلى حل مسأله دارد.

r-r-1- كمهزينهةترين جريان' (MCF)

الكوريتم بازيابى فاز كمهزينهترين جريان سعى بر بيان

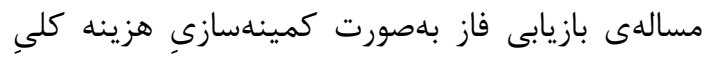

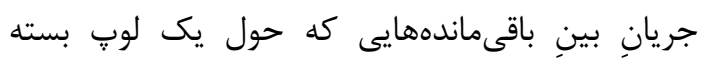

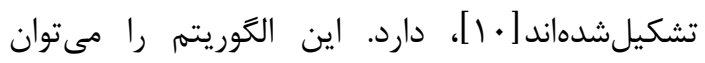
ادغامى از الكوريتهم حذف شاخهها [ب] با تئورى شبكهها دانست. يك الكوريتم MCF ساده اما دقيق بايد مراحل زير را دنبال كند:

${ }^{1}$ Minimum Cost Flow 
كه در آن K همان سيكل صحيحى است كه از مسأله

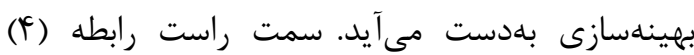

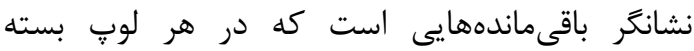

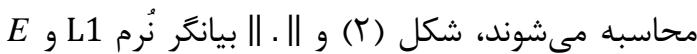

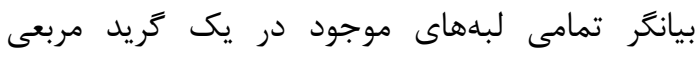
مىباشد. مقدار سيكل صحيح فازى كه نياز است

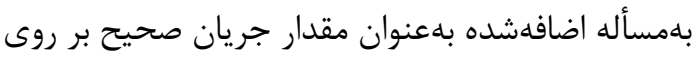
هر لبه در نظر كرفته مىشود. بلمنظور هدايت كردن

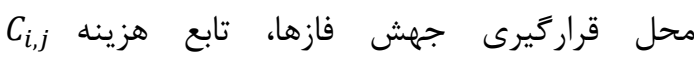

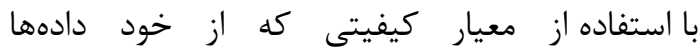

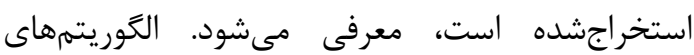

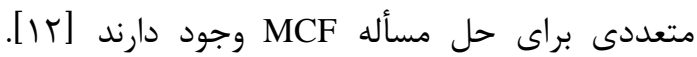
هدف حل مسأله بازيابى فاز با استفاده از كارآمدترين

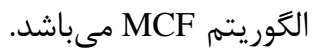

\section{r-r- r- تبديل به فضاى نامنظم به يك فضاى منظم}

خروجى روشهاى بر اساس :راكنش كنندههاى پإيدار

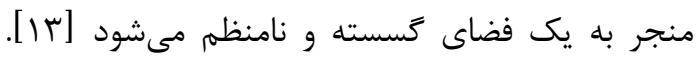
با استفاده از الكَوريتم نزديكترين همسايكى، مسألهى

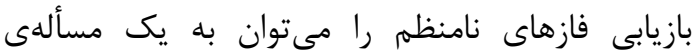

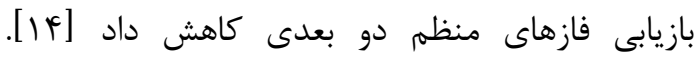

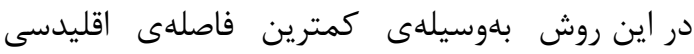
دادهها بر روى كريد درونيابى مىشوند. بررسىها

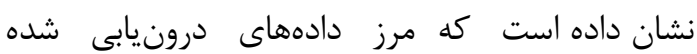

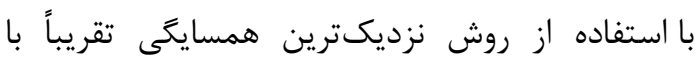

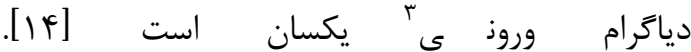

استفاده از نُرمهاى كوجىتر منجر به حلى كارآمدتر خواهد شد [ץ]. به دليل يخش شدن خطا بين نقاط، روش كمترين مربعات عادى دقت خوبى ندارد. همجنين، روش كمترين مربعات وزندار بهدليل وابسته بودن نتيجه حاصله به وزنهاى تخصيص دادهشده به به آنها،

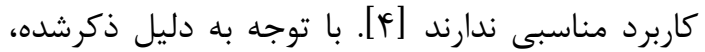
انتظار مىرود كه مساله كمينهسازى متغيرهاى صحيح، نتايج بهترى را در مسالدى بازيابى ارائه دهد.

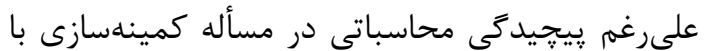

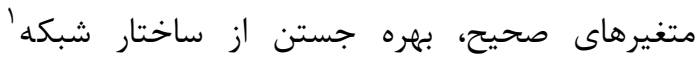
يك استراتزى مؤثر براى دستيابى به يكى جواب بهينه

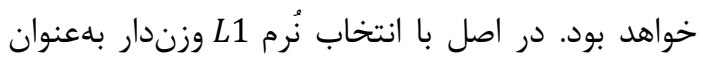
خطا، مسأله بازيابى فاز را مىتوان همارز با با مسألدى

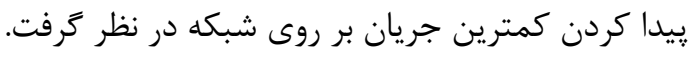
از هم ارزى بين مسأله مقيد درخت يوشاى كمينهُ و

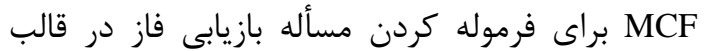

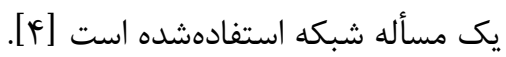

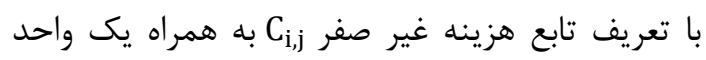
سيكل فاز بر روى هركدام از لبهها، مسألدى بازيابى فاز دو بعدى را مىتوان بلهورت يك مسألهى MCF بر روى شبكه بيان كرد [11]:

$$
\operatorname{minimize~}^{\sum_{\forall(i, j) \in E} C_{i, j} \cdot\left\|K_{i, j}\right\|}
$$

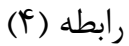

$$
\begin{aligned}
& K_{A B}+K_{B C}+K_{C D}+K_{D A}=\left[\frac{\Psi_{A}-\Psi_{B}}{2 \pi}\right]+\left[\frac{\Psi_{B}-\Psi_{C}}{2 \pi}\right]+\left[\frac{\Psi_{C}-\Psi_{D}}{2 \pi}\right]+\left[\frac{\Psi_{D}-\Psi_{A}}{2 \pi}\right] \\
& K_{i, j}: \quad \forall(i, j) \in E
\end{aligned}
$$


باقىمانده نمى دهند. جون يك بار در جهت رفت و

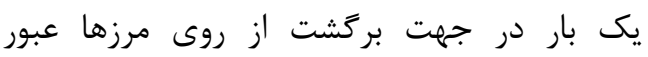

$$
\text { مى كنيم (شكل (ه- پ)). }
$$

f. محل تقاطع عمودمنصفهاى مثلث، جايى كه

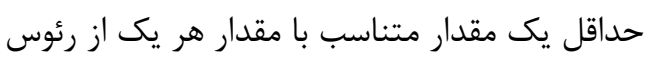
وجود دارد، مىتواند يك باقى مانده باشد (شكل (ه هـ ت)). جون هر مثلث تنها يك مركز جرم دارد، تنها

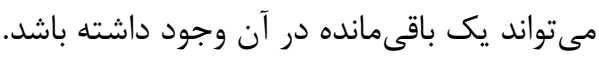
ه. كاهى اوقات به دليل مستطيلى بودن توزيع نقاط،

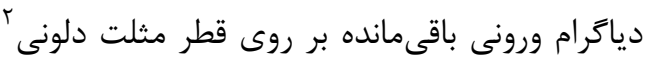

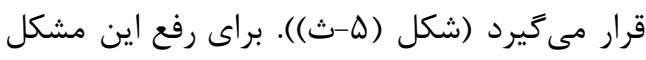

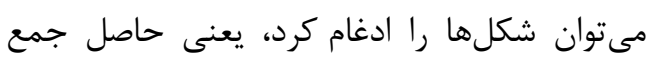

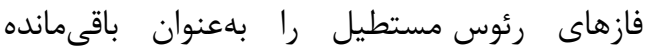

$$
\text { در نظر كرفت. }
$$

9. بنابراين باقىماندههاى موجود در دادهاى نامنظم حفظ مىشوند و در محل تقاطع عمودمنصفهاى

$$
\text { مثلثها قرار مى حيرند }
$$

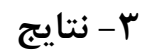

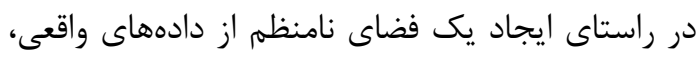

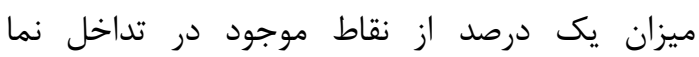

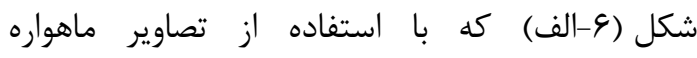
سنتينل ا ايجادشده است، انتخابشدهاند. شكل (و-ب) يك تداخل نما در فضاى نامنظه از منطقه سير إندان كرمان را نمايش مىدهد. بايد به اين نكته توجه داشت

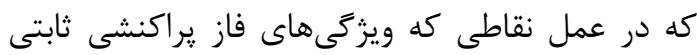

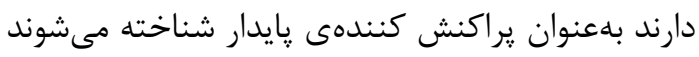

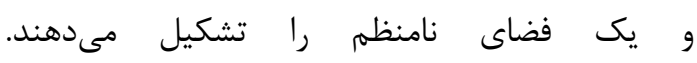

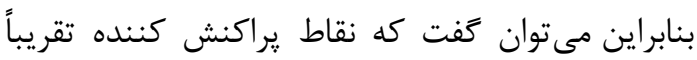

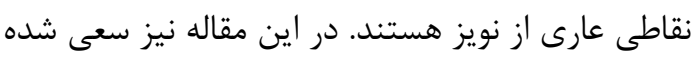
كه منطقه مطالعاتى تا حد امكان عارى از نويز باشد

${ }^{2}$ Delaunay triangulation
نحوهى انتقال دادههاى يك فضاى نامنظم به يك فضاى

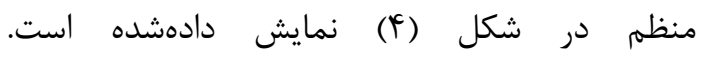
بنابراين دادهها در يك كريد كارتزين منظمه تصوير

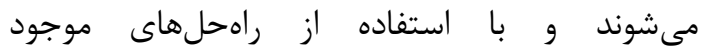
بازيابى مىشوند.

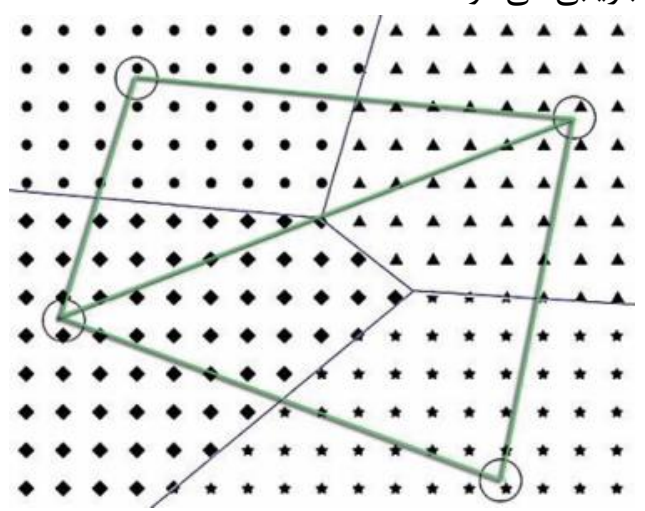

شكل \&: استفاده از يلى كونهاى ورونى براى تبديل فضاى

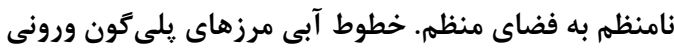

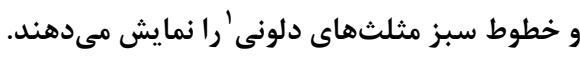
دايرههاى توخالى بيان كننده فازهاى فضاى نامنظم هستئند مىتوان نشان داد كه باقىماندهها در تبديل دادهها

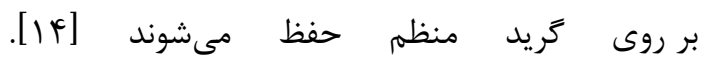

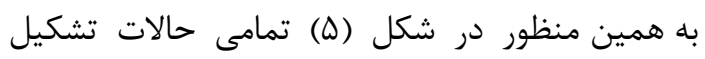

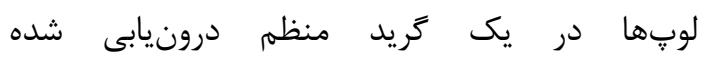
نمايش دادهشه است. در ادامه تمامى حالات تشكيل يك لوب توضيح دادهشه است.

1. لوبֶهايى كه شامل مقادير يكسان فاز هستند،

باقىماندهاى را ايجاد نمى كنند (شكل (ه-الف)).

ז. لوضٍاى تشكيلشده بر روى مرزهايى با دو نقطه از

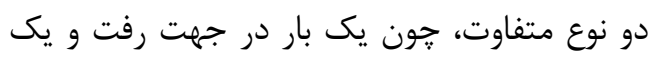

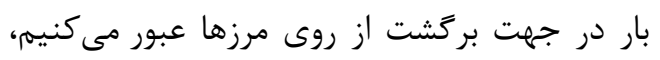
تشكيل باقىمانده نمى دهند (شكل (ه-ب)). r. لوضٍهايى كه سه نقطه يكسان و يك نقطه متفاوت در تشكيل آنها نقش داشته باشند نيز تشكيل

${ }^{1}$ Delaunay 


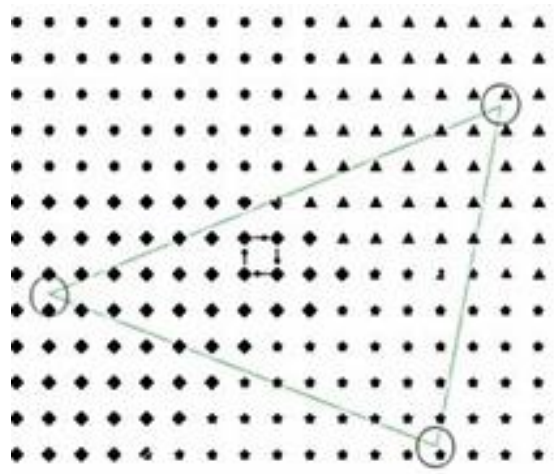

(الف)

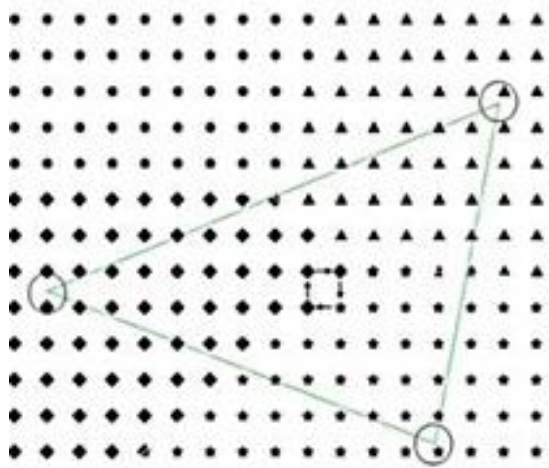
ب)

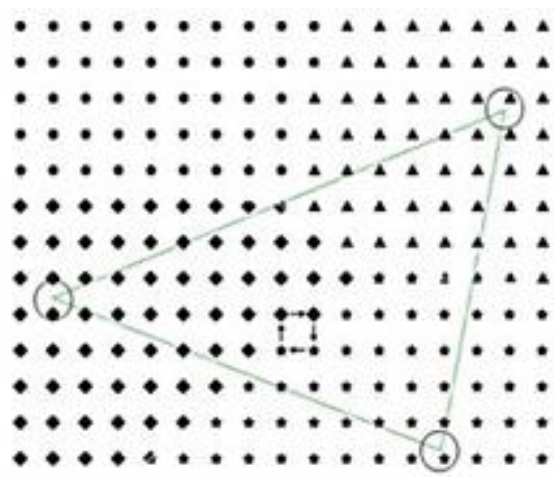

)

- $\cdot$ - . - . - A A A A A

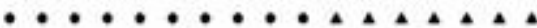
- $\cdot$ - . - - A A A A A A

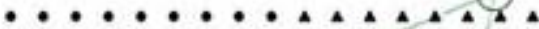

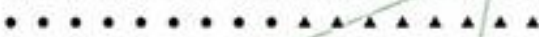

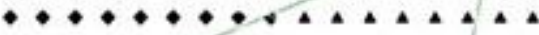

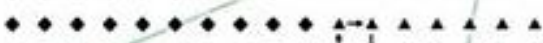

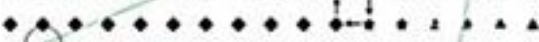
,

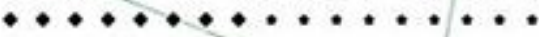

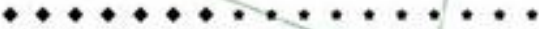

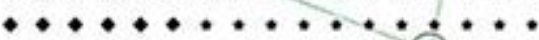

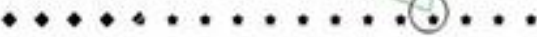

ت)

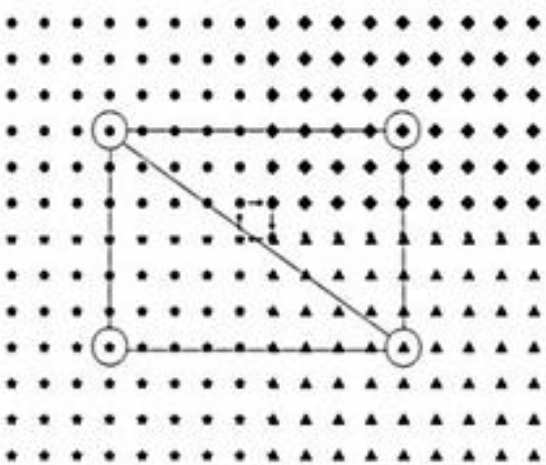

ث)

شكل ه: تمامى حالات تشكيل يك لوّ در اين تصوير نمايش دادهده است ـ نمادهاى مختلف نشانكر دادههاى نامنظم

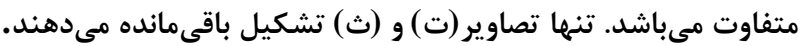

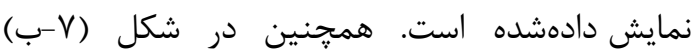
خروجى اعمال الكوريتم حذف شاخهها بر روى فضاى دمان

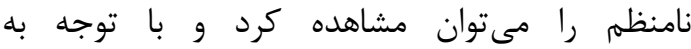
نتايج مىتوان ضعف الكوريتم در بازيابى فاز مناطقى كه فرينجها' در آن فشردهتر هستند را مشاهده كرد.

\section{${ }^{1}$ Fringes}

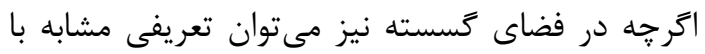
فضاى ييوسته براى باقىمانده ارائه داد، اما بايد به اين دئ دئن نكته توجه داشت كه در فضاى گسسته نمى توان تمامى نقاط باقىمانده را در نظر گرفت. اين عدم توانايى در تعيين مكان دقيق نقاط باقىمانده باعث افزايش وابستخى به مسير بازيابى فاز و كاهش دقت عملكرد الخوريتم حذف شاخهها مىشود. در شكل (V-الف)) شاخهها كه معادل با محل هاى ناييوستخى است، 


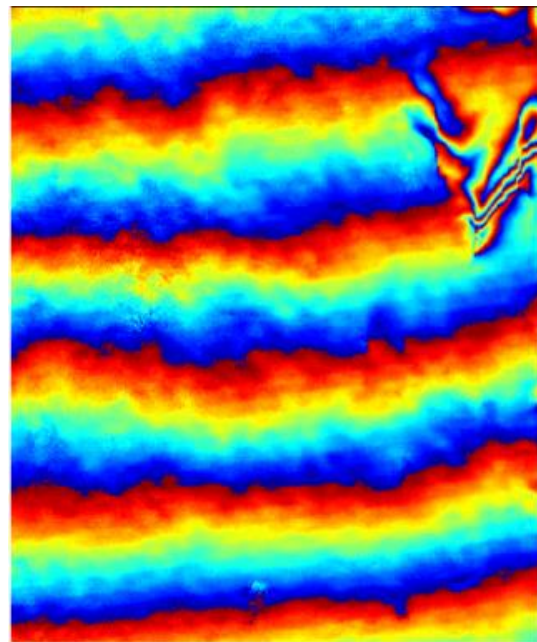

الف)

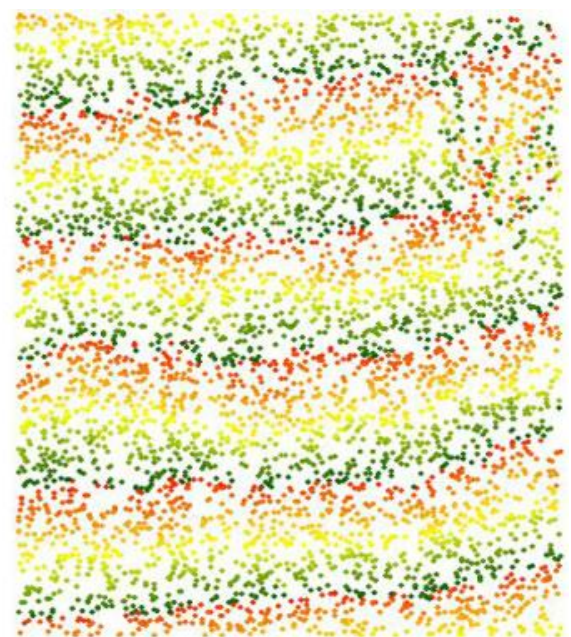

(ب)

شكل \&: تداخل نما ايجادشده با استفاده از تصاوير سنتينل ا در منطقه سيرجان. الف) فضاى منظم از تداخل نما واقعى، ب) النداء) فضاى نامنظم ايجادشده از دادههاى منظم.

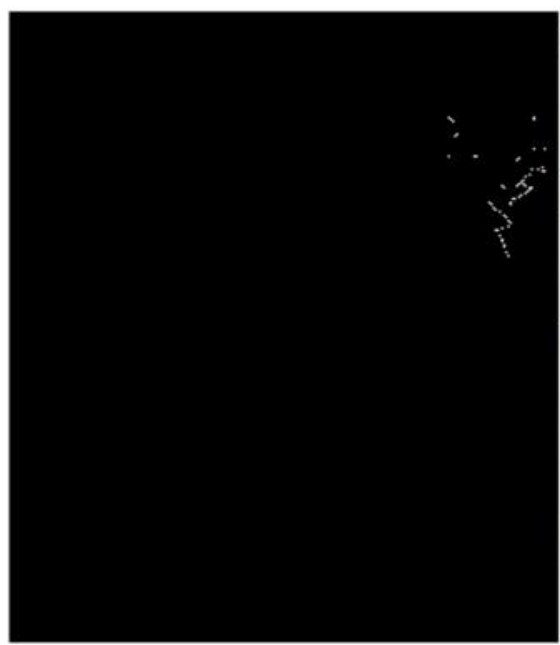

الف)

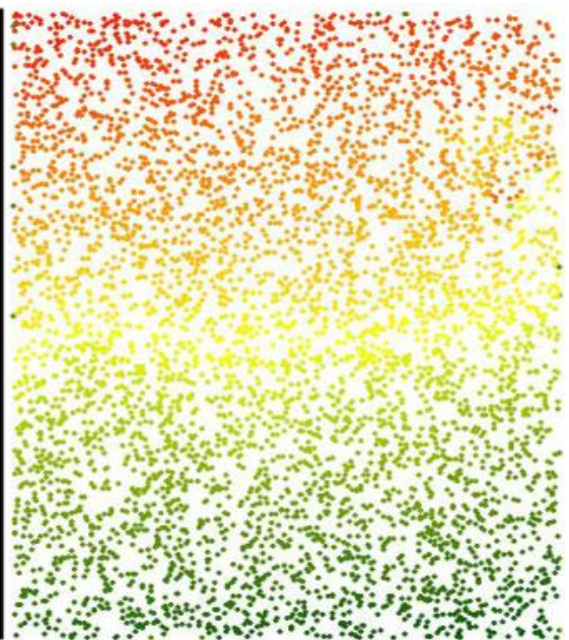

(ب

شكل V: الف) محل قراركيرى شاخه ها در سطح تداخلنما. ب) نتيجه اعمال الگَوريتم بازيابى فاز حذف شاخهها بر روى دادههاى نامنظم

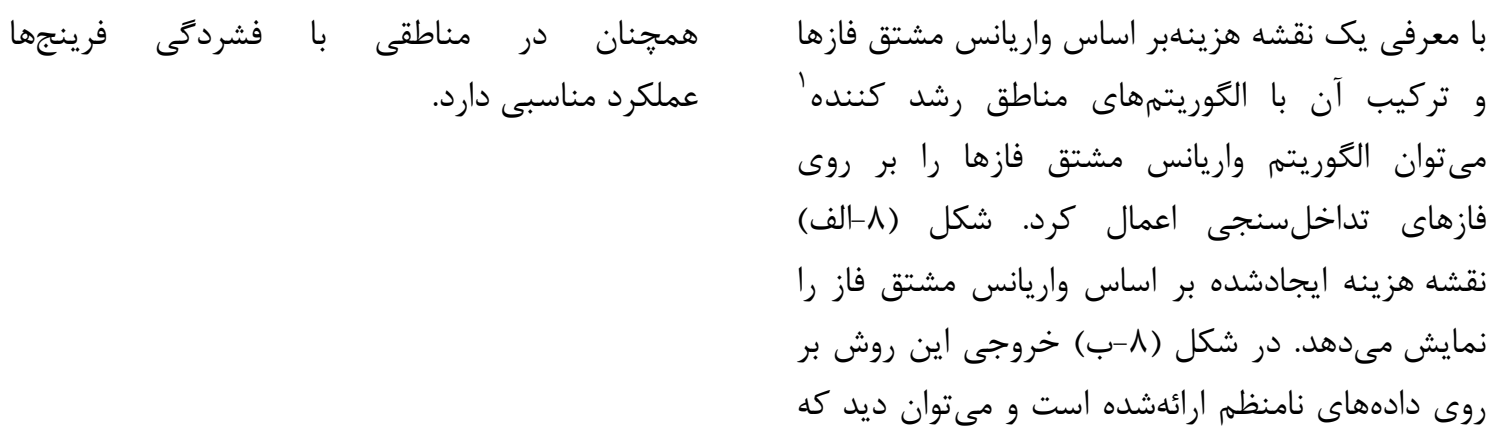

${ }^{1}$ Region Growing 


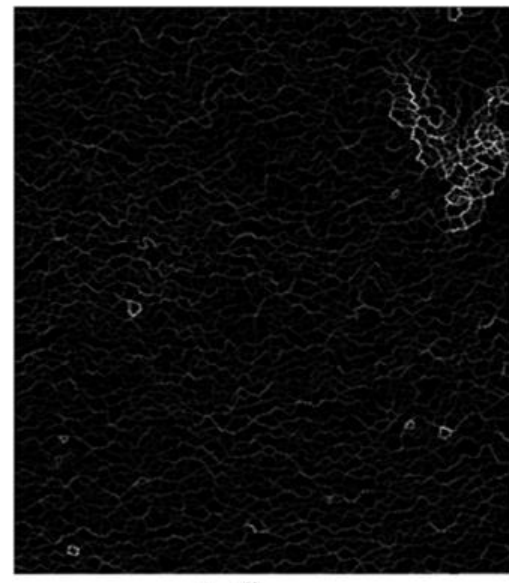

(الف)

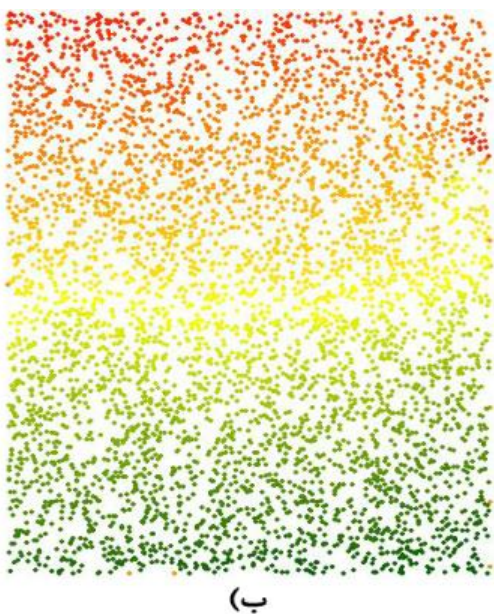

(ب

شكل^: الف) نقشه هزينه ايجادشده بر اساس واريانس مشتق فازها. ب) فازهاى تداخلسنجى بازيابى شده با استفاده از روش واريانس مشتق فازها

(الف)

شكل

است.

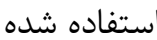

نقشه هزينهى واريانس مشتق فازها است كه با استفاده از محل قراركيرى شاخهها بهبوديافته است. مطابق

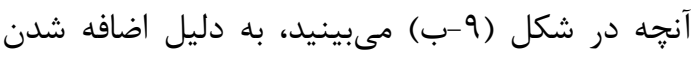

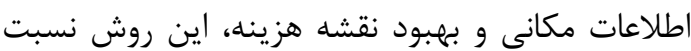
به دو روش قبل عملكرد بهترى دارد

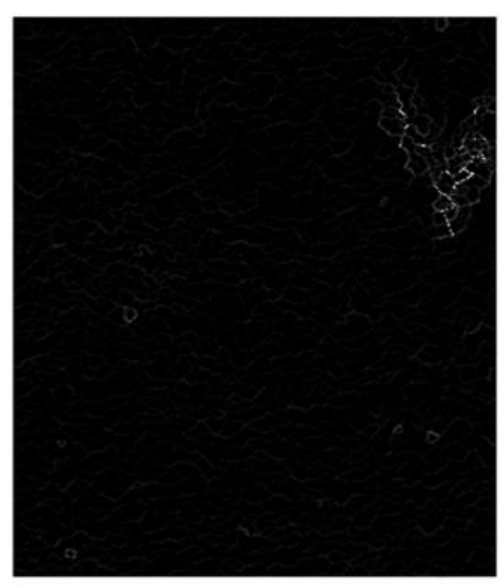

(الف)
همانطور كه مشاهده شد روش حذف شاخهها برخلاف فضاى منظم، در فضاى نامنظم عملكرد مناسبى ندارد. همجنين ديده شد كه بهرهگيرى از واريانس مشتق فازها در فضاى نامنظم نتيجه بهترى نسبت به روش حذف شاخهها داشت. در ادامه باهدف بهببود نتايج بازيابى فاز از روش واريانس مشتق فازها-حذف شاخهها

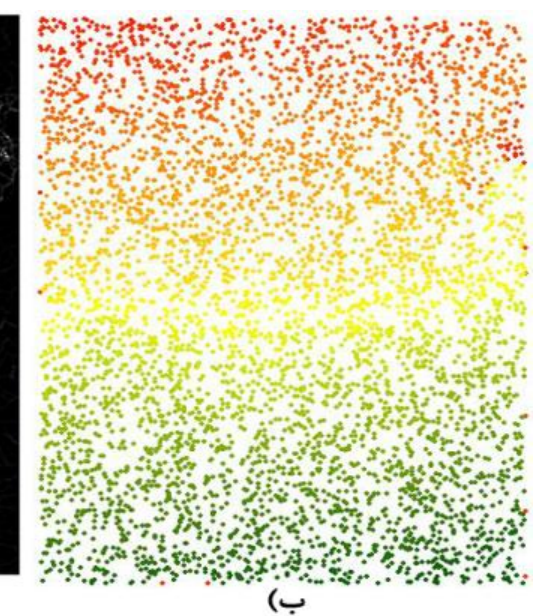

شكل 9: خروجى روش واريانس مشتق فاز -حذف شاخهها. الف) نقشه هزينه، نقاط روشن ثرهزينه ترين و نقاط تيره

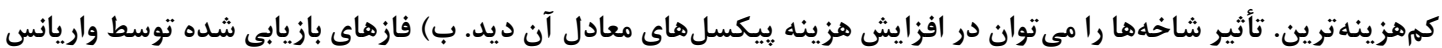

$$
\text { مشتق فازحذف شاخهها }
$$

نظير به نظير براى نقاط نمونهبردارى شده، با فازهاى - ارزيابى بازيابى شده با روش كمتر هزينهترين جريان كه يكى از بـ بهترين روشهاى بازيابى فاز در فضاى منظم مىباشد،

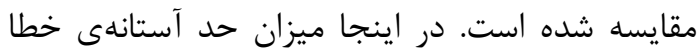

همان كونه كه بيان شد براى ارزيابى صحت نتايج،

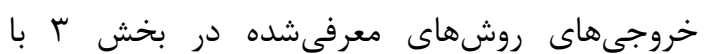
خروجى روش تداخل سنجى متداول، بلهصورت 
بازيابى فاز تداخلسنجى رادارى به كمك انتقال دادههاى...

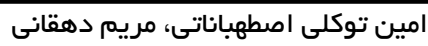

MCF در فضاى منظم نمايش دادهشه است. همجنين، بين جوابهاى دو روش برابر با ا راديان كه در تصاوير موقعيت نقاط يراكنش كنندهى انتخابى نيز با استفاده

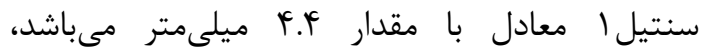
در نظر زرفتهشده است. در شكل (·) نتيجه بازيابى از نقاط مشكى بر روى تداخل نما نمايش دادهده است فازها در تداخلسنجى متداول با استفاده از الخوريتم

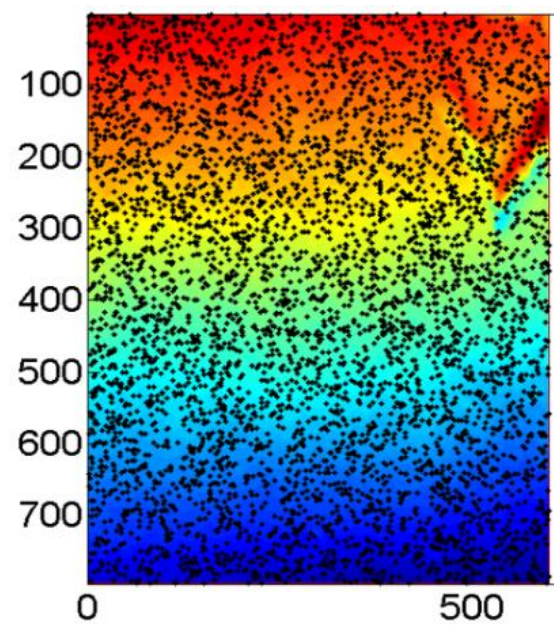

شكل •ا: تداخل نما بازيابى شده توسط الكوريتم MCF. نقاط مشكى نشاندهنده موقعيت ييكسلهاى انتخابى بهعنوان يراكنش كنندهى يايدار مىباشد.

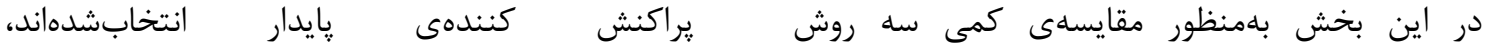

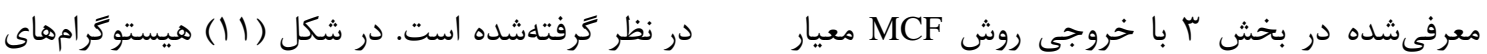

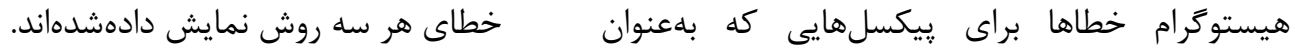

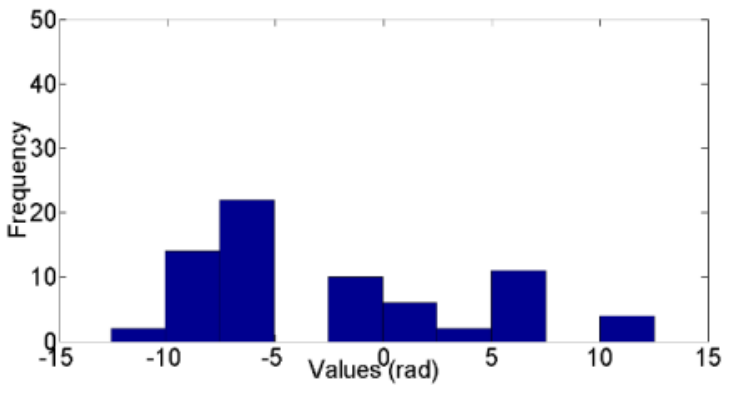

(ب)

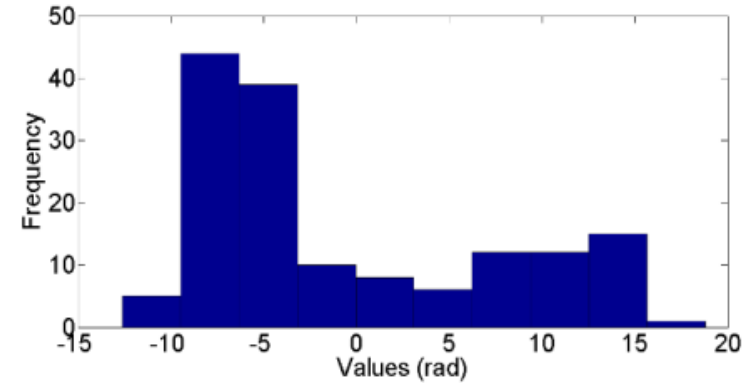

(الف)

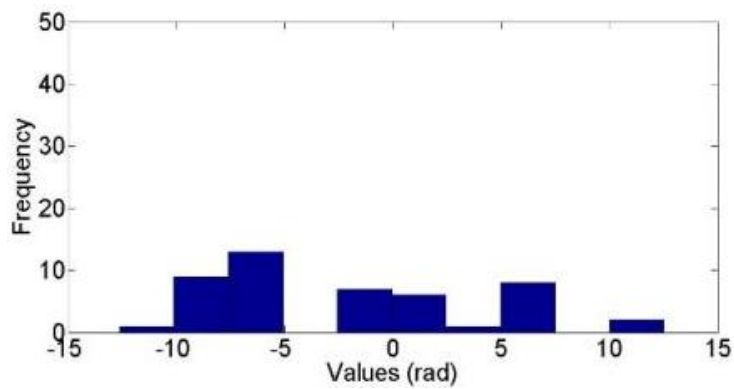

(ب)

شكل ال: هيستوكرام مقادير فازهايى كه اختلاف آنها با خروجى روش تداخلسنجى متداول بيشتر از حد آستانه مىباشد. الف،

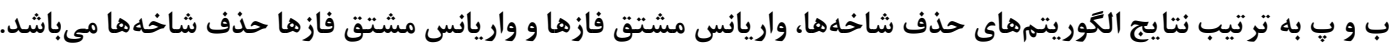




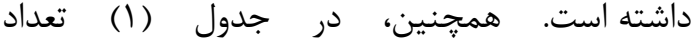
ييكسلهايى كه فازهاى آنها اشتباه برآورد شدهاند، بيانشدهاند.

با مقايسهى هيستوكرامهاى شكل (1 (1) مىتوان ديد كه الكوريتم واريانس مشتق فازها- حذف شاخهها عملكرد بسيار مناسبترى را در مقايسه با ديخر روشها جدول ا: تعداد يِيكسلهايى كه بهاشتباه بر آورد شدهاند

\begin{tabular}{|c|c|c|c|}
\hline حذف شاخهها - واريانس مشتق فازها & واريانس مشتق فازها & حذف شاخهها & \\
\hline iv & (1) & lQT & 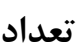 \\
\hline
\end{tabular}

هستند كه نتيجه اين روشها يك فضاى نامنظه از

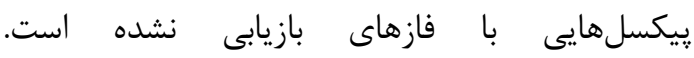
يافتن اطلاعات جابجايى از فازهاى بازيابى نشده در يكى بازئ

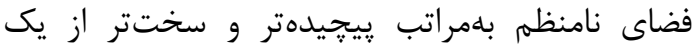

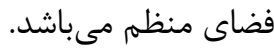

يك روش بيشنهادى براى بازيابى فاز در فضاى نامنظهم

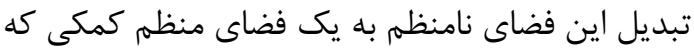

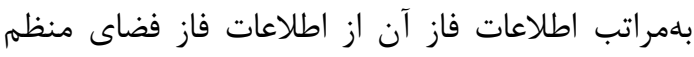

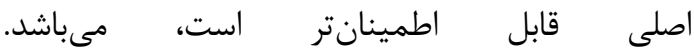
يكى از مناسبترين روشها براى رسيدن به فضاى

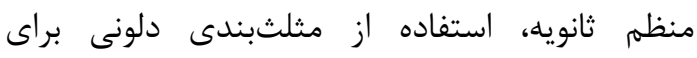

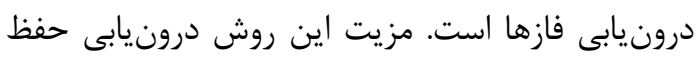
ماهيت فازها است. يس از انتقال به فضاى منظم كمكى دازي مىتوان روشهاى بازيابى فاز در فضاى منظهم را بر روى إن إنى فضاى منظم حاصلشده از يراكنش كنندههاى پايدار اعمال كرد. همانطور كه در بخش قبل مشاهده شد، برخلاف فضاى منظه، بهدليل از دست رفتن اطلاعات مربوط به برخى از باقىماندهها، الكوريته واريانس

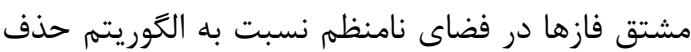

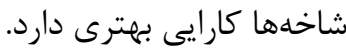

[1] C W Chen and H A Zebker, "Phase Unwrapping for Large SAR Interferograms: Statistical Segmentation and Generalized Network Models," IEEE Transactions on
با توجه به جدول (1) و شكل (1) مىتوان ديد كه الكَوريتم واريانس مشتق فازها- حذف شاخهها نسبت به به دو روش ديخر نتايج بهترى را آرايه مى كند. همجنيني، مى توان ديد كه برخلاف فضاى منظم، در فضاى نامنظه

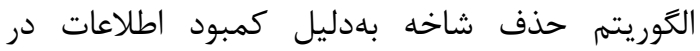
شناسايى محل تمامى باقىماندهها، عملكرد بهمراتب ضعيفترى نسبت به الكوريتم واريانس مشتق فازها

در ساليان اخير به سبب افزايش استفاده از تصاوير

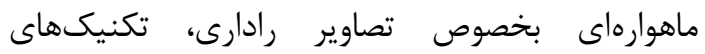
تداخلسنجى رادار با روزنه مصنوعى نقش ويزهاى در

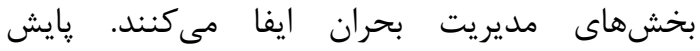

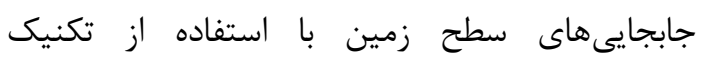

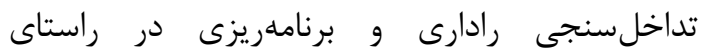
جلوكيرى و كاهش خسارات ناشى از جابجايىها

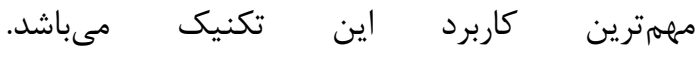

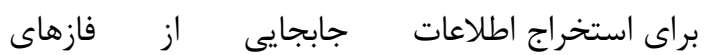
تداخلسنجى بايستى فازهاى تداخلنما بازيابى شوند. به دليل وجود نقاط نويزى در سطح تداخل نما روشهاى بر مبناى براكنش كنندههاى بايدار به دئ دنبال انتخاب پيكسل هاى با كمترين احتمال آغشتكى به نويز

Geoscience and Remote Sensing, vol. 40, no. 8, pp. 1709-1719, 2002.

[2] D C Ghiglia and L A Romero, "Robust two- 
بازيابى فاز تداخلسنجى رادارى به كمك انتقال دادههاى...

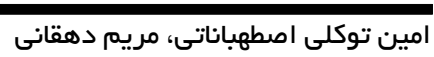

dimensional weighted and unweighted phase unwrapping that uses fast transforms and iterative methods," The Optical Society of America A, vol. 11, no. 1, pp. 107-117, 1994.

[3] R M Goldstein, H A Zebker, and C L Werner, "Satelite radar interferometry : Two-dimentional phase unwrapping," Radio Science, vol. 23, no. 4, pp. 713-720, 1988.

[4] C W Chen and H A Zebker, "Network apploaches to two-dimentional phase unwrapping intractability and two new algorithm," The Optical Society of America, vol. 18, no. 3, pp. 401-414, 2000.

[5] B Osmanoglu, T H Dixon, S Wdowinski, and E Cabral-Cano, "On the importance of path for phase unwrapping in synthetic aperture radar interferometry," Applied Optics, vol. 50, no. 19, pp. 3205-3220, 2011.

[6] B R Hunt, "Matrix Formulation of the Reconstruction of Phase Values from Phase Diffrences," The Optical Society of America $A$, vol. 69, no. 3, pp. 393-399, 1979.

[7] D C Ghiglia and M D Pritt, TwoDimentional Phase Unwrapping: Theory, Algorithms and Software.: WileyBlackwell, 1998.

[8] Howard A Zebker and Yanping Lu, "Phase unwrapping algorithms for radar interferometry: residue-cut, least-squares, and synthesis algorithms," The Optical
Society of America A, vol. 5, no. 3, pp. 586598, 1998.

[9] D C Ghiglia and Louis A Romero, "Minimum Lp-norm two-dimensional phase unwrapping," The Optical Society of America A, vol. 13, no. 10, pp. 1999-2013, 1996.

[10] M Costantini, "A novel phase unwrapping method based on network programming," IEEE Transactions on Geoscience and Remote Sensing, vol. 36, no. 3, pp. 813-821, 1998.

[11] Piyush Agram and Howard Zebker, "Edgelist Phase Unwrapping Alghorithm fot Time Series," in Fringe Workshop, Frascati, Italy, 2009.

[12] R K Ahuja, T L Magnanti, and J B Orlin, Network Flows: Theory, Algorithms, and Applications.: Englewood Cliff-New Jersey, 1993.

[13] Andrew Hooper, "A multi-temporal InSAR method incorporating both persistent scatterer and small baseline approaches," Geospatial Research Letters, vol. 35, no. 16,2008 .

[14] Piyush Shanker Agram and Howard A Zebker, "Sparse Two-Dimensional Phase Unwrapping Using Regular-Grid Methods," IEEE Geoscience and Remote Sensing Letters, vol. 6, no. 2, pp. 327-331, 2009. 


\title{
InSAR Phase Unwrapping by Transforming Sparce Data into a Regular Space
}

\author{
Amin Tavakkoli Estahbanati ${ }^{* 1}$, Maryam Dehghani ${ }^{2}$
}

1- M.Sc. of remote sensing in Department of Civil and Environmental Engineering, School of Engineering, Shiraz University

2- Associate professor in Department of Civil and Environmental Engineering, School of Engineering, Shiraz University

\begin{abstract}
Phase unwrapping is one of the most important parts of InSAR techniques. In order to estimate the grand surface displacements, interferomtric phases modulated between 0 to $2 \pi$ must be unwrapped. Based on the use of either the conventional method or persistent scatterer (PS), phases will be spread both regularly and irregularly. The phases of PSs can be unwrapped by reducing phases into a regular and continues grid with neatest neighbor interpolation method. In this paper, beside Minimum Cost Flow (MCF) as a global unwrapping method, three local unwrapping methods (Branch-cut, Phase Derivative Variance and Branch cut-Phase Derivative Variance) are introduced as well. These conventional unwrapping approached are implemented on an irregular interferogram processed from SentinallA satellite images acquired over the Sirjan basin. At the end, the results of these approaches are assesed with unwraped phase which is resulted in a conventional interferogram unwrapped with MCF method.
\end{abstract}

Key words: Interferometry, Phase unwrapping, SentinellA.

Correspondence Address: Department of Civil and Environmental Engineering, School of Engineering, Shiraz University, Shiraz, Iran.. Tel: +989171018975 .

Email: amintavakkoli.est@gmail.com 